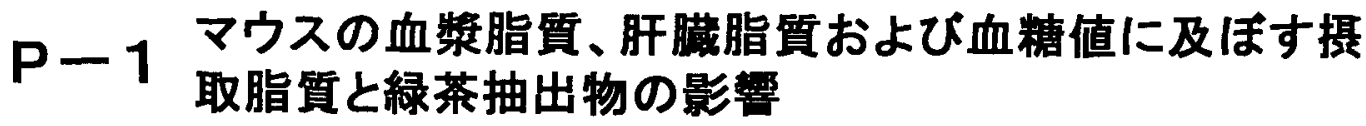

独立行政法人食品総合研究所

○白井展也・鈴木平光

【目的】現在、糖代謝調節機構の異常が原因の糖尿病患者は 700 万人おり、 その予備軍を含めると 1500 万人いると推定されている。また今後糖㽷病 患者の増加が予測されている。この糖尿病の 95\%は生活習慣が関係してい るとされ、循環器系疾患、神経症、網膜症等を合併することが知られてい る。一方、循環器系疾患の予防には、日本型食生活が有効であることが知 られている。日本型食生活の特徵の一つは、魚介類や緑茶を多く摂取する ことにある。最近では、搨取脂肪の n-6/n-3 が心疾患系の疾病と関わりが あると報告され、摂取脂肪の脂肪酸組成は重要であると考えられる。本研 究では、実際に我々が摄取している脂肪に準じた脂質と微量の緑茶抽出物 を含んだ飼料を調製し、これらの飼料を摂取したマウスの血漿および肝葴 脂質および血糖値に与える影響について検討した。

【方法】欧米（動物脂：植物油 : 魚油= 5.5:4.4:0.1）、菜食 $(0: 10: 0)$ および日本型（4:5:1）の食生活に準じた脂質を調製した。2 月月龄の雄性 マウス Crj:CD-1(ICR)に脂質含量を $10 \%$ に調製した各脂質型飼料およびそ れぞれに $0.03 \%$ 緑茶抽出物を含む飼料を 7 ケ月間与えた。動物脂はラー ド:牛脂 $=2: 1$ 、植物油は大豆油: 菜種油=1:1、および魚油は $20: 5 n-3 / 22: 6 n-3$ が 0.5 になるようにそれぞれ調製した。飼育期間終了後、血液および肝臓 を採取し、血槳および肝葴中の総コレステロール(T·Chol)、中性脂肪 (TG)、 リン脂質（PL）含量および血糖值を測定した。

【結果】血獎および肝臓中の $\mathrm{T} \cdot \mathrm{Chol}$ 含量は欧米、菜食および日本型脂質 群で有意差が認められなかった。TG 含量は血墏中では菜食>日本>欧米 型の順で高い傾向にあり、肝臓中では菜食型脂質群で有意に高かった。緑 茶抽出物の添加は菜食型脂質群で血槳および肝葴中の TG 含量を有意に低 下させたが、欧米および日本型脂質群では血獎および肝臓中の脂質に緑茶 抽出物の添加による有意な差が認められなかった。血糖値は欧米〉菜食〉 日本型脂質群の順で高く、緑茶抽出物の添加は各脂質群の血糖值を低下さ せる傾向にあった。

【考察】これらの事から、日本型脂質および緑茶の摄取注血糖值の低下に 有効である事が示唆された。 


\section{P-2 高コレステロール食投与における糖尿ラットの
腎間質における抗原提示細胞と線維芽細胞の動態}

千葉県立衛生短大 $\cdot$ 栄養学科 ${ }^{1)}$ 、順天堂大学医学部 ・第 I 解剖 ${ }^{2}$ ○細山田康恵 ${ }^{1)}$ 、栗原秀剛 ${ }^{2}$ 、坂井建雄 ${ }^{2)}$

[目的] 健常ラット腎間質には、抗原提示細胞機能を有する樹状細胞と線 維芽細胞があることが知られている。本実験では、ストレプトゾトシン糖 尿病ラットに高コレステロール食を投与した場合の腎間質に存在する抗原 提示細胞と線維芽細胞の動態㧍よび構造変化を検討する。

[方法] 4 週齢 SD 系雄ラットを 1 週間予備飼育し、予備飼育開始時にス トレプトゾトシンを腹腔内注射し、糖尿ラットとした。高コレステロール 食は、AIN-93 に準じた基礎飼料に 0.5\%コレステロールと 0.25\%コール 酸ナトリウムを含む飼料とし、3 週間投与した。実験飼料投与終了後、腎 臓を灌流固定し、低温脱水法により試料を作成した。腎間質の細胞を光学 および電子顕薇鏡にて観察した。また、抗原提示細胞の樹状細胞とマクロ ファージに関して、免疫染色を行い、健常ラットと高コレステロール食投 与糖尿ラットにおける差異を検討した。

[結果] 健常な腎間質には、それぞれの基底膜によって囲まれた中に、免 疫機能を有する樹状細胞と線維芽細胞が観察された。樹状細胞は、線維芽 細胞に比べ不規則な短い突起が見られ、突起内は明るく見えた。線維芽細 胞の突起が基底膜に接する部分では、アクチンフィラメントが基底膜に平 行に走行していた。細胞質は、粗面小胞体やリボソームが豊富に認められ、 かなりの暗顆粒を含んでいるように見えた。高コレステロール食投与糖尿 ラットでは、脂肪滴をもった泡沫細胞が間質に增え、細胞質は、粗面小胞 体やゴルジ体が大きくなり、コラーゲン線維の束が目立つことが電顕的に 観察された。免疫染色において、マクロファージを認識する ED1 陽性の 細胞が増加し、MHC classII 分子を認識する OX6 陽性の細胞はほぼ消失 していた。

[考察] 高コレステロール食投与糖尿ラットの尿細管周囲間質では、マク ロファージを認識する ED1 陽性の細胞が增加し、MHC classII 分子を認 識する OX6 陽性の細胞はほぼ消失していたことから、樹状細胞がマク口 ファージに置き換わったことが示唆された。また、健常ラットの腎間質に おいても、コラーゲン線維の豊富な動脈周囲ではマクロファージの分布が みられるので、細胞外基質の增生と樹状細胞からマクロファージへの移行 になんらか関係があると予想される。 


\section{$P-3^{\mathrm{n}-3}$ 高度不飽和脂肪酸の不足がドコサヘキサエン酸の 代謝に及ぼす影響}

\section{- ${ }^{13} \mathrm{CO}_{2}$ 呼気テストによる脂肪酸酸化の評価一}

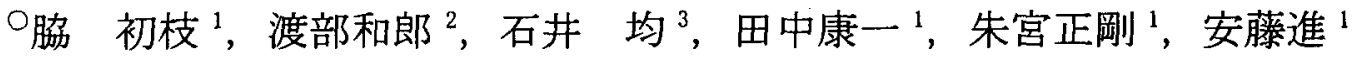
1 東京都老人総合研究所， ${ }^{2}$ 相模中央化学研究所， ${ }^{3}$ アルコシステム

【目的】食蝕中の $n-3$ 系列高度不飽和脂肪酸（ $n-3$ PUFA）の不足が, ラッ ト体内の脂肪酸酸化に及ぼす影響を， $\left[{ }^{13} \mathrm{C}\right]$ 標識脂肪酸を用いた $\mathrm{CO}_{2}$ 呼気 テストによって明らかにする。

【実験方法】F344 ラットを 2 群に分け，グループ 1 には市販の長期飼育用 飼料（n-3 PUFA 含量：156 mg/100 g 飼料）を，グループ 2 には $\mathrm{n}-3$ PUFA 不足食（ $\mathrm{n}-3$ PUFA : $52 \mathrm{mg} / 100 \mathrm{~g}$ 飼料）を与えて長期飼育した。ラット（F18） の頸静脈から $\left[\mathrm{U}-{ }^{13} \mathrm{C}\right]$ ドコサヘキサエン酸 (DHA) を投与し, 呼気中の ${ }^{13} \mathrm{C} /{ }^{12} \mathrm{C}$ 比を質量分析計で経時的に測定して， ${ }^{13} \mathrm{CO}_{2}$ 消失の半減期と排出された ${ }^{13} \mathrm{CO}_{2}$

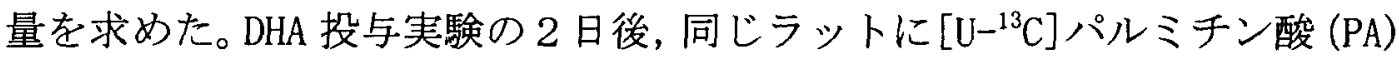
を投与して同様に呼気テストを行った。 $\left[{ }^{13} \mathrm{C}\right]$ 標識脂肪酸は， $\left[1,2-{ }^{13} \mathrm{C}\right]$ 酢 酸ナトリウム添加培地で培養した Thraustochytrid の脂質から調製した。

【結果】 $\left[{ }^{13} \mathrm{C}\right]$ 標識脂肪酸投与後 $3 \sim 5$ 分で呼気中の ${ }^{13} \mathrm{CO}_{2}$ 濃度が最大とな った。その後，呼気中の ${ }^{13} \mathrm{CO}_{2}$ は指数関数的に消失した。DHA 投与実験で， ${ }^{13} \mathrm{CO}_{2}$ 消失の半減期はグループ間で有意の差はなかったが， ${ }^{13} \mathrm{CO}_{2}$ 排出量はグ ループ 2 ではグループ1の 60\%に低下していた。PA 投与実験では ${ }^{13} \mathrm{CO}_{2}$ 消 失の半減期， ${ }^{13} \mathrm{CO}_{2}$ 排出量ともグループ間で差はみられなかった。

【考察】食餌中の n-3 PUFA 不足により，ミトコンドリアでのPA の $\beta$ 酸化 は影響を受けないが，ペルオキシソームでの DHA の $\beta$ 酸化が抑制されるこ とが示唆された。 $\left[{ }^{13} \mathrm{C}\right]$ 標識脂肪酸を用いた呼気テストは，非侵襲的な体 内の脂肪酸酸化の測定に有効であった。 


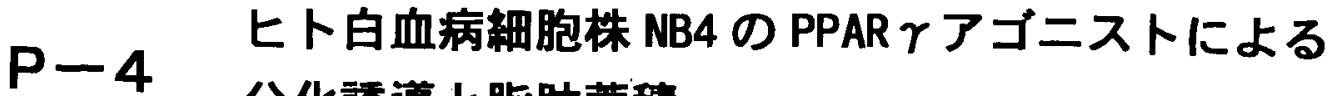 分化誘導と脂肪蓄積}

○大熊恵美子 1 , 八杉悦子 1 , 堀内晶子 2 , 中津雅美 1 , 佐伯久美子 1 , 湯尾明 1 1 国立国際医療センター研究所、2 国際基督教大学

【目的】PPARyのアゴニストであるプロスタグランジンJ2 (PGJ2) やピ オグリタゾン(AD4833、糖尿病薬) は、PPAR $\gamma$ を介してその下流にある 脂質や糖質に関わる遺伝子の発現の制御や細胞分化に関連していると いわれている。今回は、ヒト白血病細胞株NB4を用いてこれら薬剤によ る分化誘導および紐胞内脂質動態を調べた。

【方法】 NB4 株を AD4833(50 $\mu \mathrm{M}), \mathrm{PGJ} 2(4 \mu \mathrm{M})$ およびレチノイン酸 (ATRA, 1nM)で分化させた。細胞分化の指標はNBT 還元能、ギムザ染 色による形態観察および CD11b の発現によった。細胞内脂質動態は nile red 細胞染色、脂質抽出後薄層クロマトグラフィー、トリアシルグ リセロール(TG)定量キットにより同定した。また、グリセロール 3 燐 酸脱水素酵素(GPDH)活性は分光光度法により測定した。

【結果】NB4 細胞は ATRA と AD4833 PGJ2 との組合せにより好中球 系への分化誘導が観察された。AD4833, PGJ2 いずれの場合も分化した 細胞の細胞質には lipid droplet の著明な増加が認められた。脂質分析に より増加した脂質は TGであることから lipid dropletには TG が蓄積さ れていると考えられた。脂肪合成に関わる酵素 GPDH 活性は低く、 ATRA および PGJ2 を作用させても変化が認められなかった。

【結論】PPAR $\gamma$ リガンドによりヒト白血病細胞株 NB4 は食細胞系へ分 化し、また脂質代謝が活性化されて TG の貯留が認められた。 


\title{
Pー5 ホスファチジルセリン投与の加齢マウス海馬に対する影響
}

\author{
日本油脂株式会社筑波研究所 \\ ○田中幸久
}

【目的】学習能改善など脳神経系に対してさまざまな効果が認められているホ スファチジルセリン(PS)を加齢マウスに投与し、記憶・学習の獲得に媣く関与 する海馬に対する影響を検討する。

【方法】4,70 週齢の雄性 ICR マウス(以下、前者を若齡群、後者を加齢群と称 す)に、 4 週間コーン油(Control)、大豆リン脂質(Soy-PL)、大豆リン脂質より塩 基交換反応によって得た大豆ホスファチジルセリン(Soy-PS)、DHA を高濃度 に含有するリン脂質(イクラより抽出 : DHA-PL)、DHA-PL より塩基交換反応 によって得たホスファチジルセリン(DHA-PS)を 4.8\%添加した飼料を与えた。 投与終了後に屠殺し、脳より海馬を摘出し、脂質組成を分析した。

【結果】若龄群では Control 飼料投与群に対してその他のいずれの 4 飼料投与 群では海馬中の PS 含量は増加あるいは増加傾向を示した。加歯群の Control, Soy-PL, DHA-PL 飼料投与群ではいずれも海馬中の PS 含量は若齢の Control 群 に対して 15-35\%にまで減少していた。一方、加齢の Soy-PS, DHA-PS 飼料投 与群では、それらの海馬中の PS 含量は若齢の Control 群とほとんど同量であ つた。

【考察】加龄によって低下した海馬中の PS 含量は PS の経口摄取によって回 復することが示された。経口搨取されたPS は血液䋞関門を通過し、海馬中に 供給されたことが示唆された。

【結論】1) マウスでは加齢により海馬中の PS 含量が著しく減少した。2)こ の減少はホスファチジルコリンやホスファチジルエタノールアミンなどリン 脂質を豊富に含有するSoy-PL, DHA-PLの経口投与によっては補うことは出来 なかった。3) Soy-PS, DHA-PS の経口投与により加齢で減少した海馬中の PS 含量を若齢マウスのそれと同程度まで回復することが可能であった。

加齢によって低下する記憶学習機能はPS の摄取によるアセチルコリン量の 増加などによって改善される可能性が示唆された。 


\section{P-6 血清脂質動態に関与する制御因子遺伝子発現の 食䬣油脂による調節}

三重大学生物資源学部

○住岡美由貴、篠原亜理、海津理絵、原 貴子、森嶋克典、藤岡敏明、 古市幸生

【目的】

食餌油脂は、その種類によって血清や肝䁍のコレステロールやトリアシ ルグリセロールなどの脂質レベルに異なる影響を及ぼす。本研究では、 その調節機構をさぐることを目的として、脂肪酸組成が顕著に異なる 5 種類の食用油脂をラットに与えて、血清および肝臓脂質プロフィールな らびに血清コレステロール濃度の調節に関与する因子の遺伝子発現につ いて検討した。

\section{【方法】}

水素添加ヤシ油、高リノール酸サフラワー油、高オレイン酸サフラワー 油、シソ油、魚油をそれぞれ20\%含有したAIN93凖拠の精製飼料をコレ ステロール無添加および 1 \%添加で調整し、4 週齢Wistar系雄性ラット に3 週間与えた後、腹部大動脈から採血し、併せて肝㵴を摘出した。血 清脂質濃度は市販キットにて測定し、肝臓脂質はFolch法による総脂質抽 出液について市販キットにて分析した。肝臓については、3-ヒドロキ シー3-メチルグルタリルCoA還元酵素（HMG-CoA還元酵素、HMGR と略 称）とコレステロール $7 \alpha$-水酸化酵素（CYP7A1、CYP7と略称）の酵 素活性とmRNA発現、低密度リポタンパク質受容体（LDLRと略称）の mRNA発現を測定した。なお、mRNA発現量の測定はノーザン法にて行 つた。

\section{【結果】}

コレステロール無添加食の場合

(1) 血清総コレステロール濃度は高オレイン酸サフラワー油群で高く、 シソ油群で低い傾向を示した。

(2) HMGR活性およびmRNA発現は、高リノール酸サフラワー油群で 高く、魚油群で低かった。

(3) 魚油群でのLDLRmRNAは顕著に低かった。 コレステロール添加食の場合

（1）水素添加ヤシ油群と魚油群で血清総コレステロール值は高かった。

(2) 水素添加ヤシ油群のCYP7mRNA とLDLRmRNA発現は高かった。

(3) 魚油群のCYP7mRNAとLDLRmRNA発現は低かった。

\section{【考察】}

食䬣油脂はその種類により、遺伝子発現特徵的な影響を及ぼすことが示 された。今後はSREBPなど上位の制御因子との関連の検討を考えている。 


\section{アマニ油、レシチン、ビタミン $E$}

飼料添加による高付加価值豚肉の試作

北陸学院短期大学食物栄養学科 1 , 石川県畜産総也夘 -2 , 日清才们才(株) 研究所 ${ }^{3}$

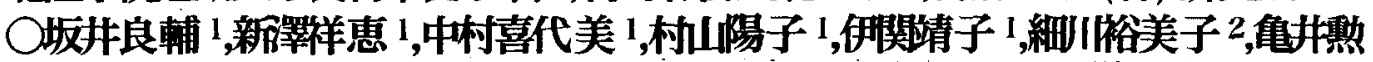
${ }^{2}$,三木伊佐雄 2 ,常川久三2,堀久夫 ${ }^{2}$,村野貿博 3 ,船橋智子 ${ }^{3}$,山口貴宏 ${ }^{3}$,柏倉真 ${ }^{3}$

【目的】第 6 次改訂「日本人の栄養所要量」において n-3 系、n-6 系多 価・高度不飽和脂肪酸の摄取比率 $(\mathrm{n}-6 / \mathrm{n}-3$ 比) を 4 程度とするように報 告された。豚肉は良貿タンパク質およびビタミン B1 の補給源とされて いるが、その脂質の脂肪酸組成は飽和、一価不飽和脂肪酸で約 $70 \%$ をし め、多価不飽和脂肪酸ではリノール酸 (C18:2) が約 10\%で一番多く、 $\alpha$ ーリノレン酸 (C18:3) は少量であるため n-6/n-3 比は 20 前後を示す。我々 は肉豚用飼料に $\alpha$-リノレン酸を多く含む植物油のアマニ油を混合し、豚 肉脂賀に $\alpha$-リノレン酸を移行させ、n-6/n-3 比が 4 程度に改善された豚 肉をつくることに成功した。しかし、豚肉脂質中の多価不飽和脂肪酸含 有率が上昇するにつれ、保存安定性低下が認められた。今回我々は飼料 にアマニ油 1.5\%の他にさらに大豆レシチン $1.0 \%$ 、ビタミン E 100 IU/kg を加えることにより、n-3 系高度不飽和脂肪酸含有率を高めて栄 養強化を達成しつつ、脂肪融点降下抑制効果および保存安定性も合わせ 持つ豚肉の生産を試みた。【方法】LWD 豚を 1 群につき 7 頭、それぞ れ肉豚用飼料のみ、肉豚用飼料にアマニ油+レシチン+ビタミン E、アマ 二油+ビタミン E、アマニ油+大豆油+ビタミン E 添加の 4 群にわけ、生 後 5 ヶ月〜 6 ケ月の 67 日間給与した。各群の一般肉質検查、保存安定性、 V.E.含量、レシチン含量、コレステロール含量、脂肪酸組成、 $n-6 / n-3$ 比、TBARS 值、脂肪融点を測定した。【結果および考察】n-6/n-3 比は 対照区を除くそれぞれの群で従来道り、アマニ油添加による低下が認め られた。TBARS 值はアマニ油添加群の上昇が著しいものであったが、 レシチン添加群は肉豚用飼料群と同じ程度に上昇が抑えられた。脂肪酸 組成が同等にも関わらず、脂肪融点はレシチン添加群が大豆油添加群よ りも高く、レシチンの投与が脂肪曧点降下を抑制させている可能性が示 唆された。これよりアマニ油、レシチン、ビタミン E を飼料に添加する ことにより通常より栄養価が高く、また同等の保存安定性をもつ豚肉を 生産できることが示された。 
杏林大学保健学部学術フロンティア研究グループ

○田地野和宏、辻井岳雄、下島裕美、山上雅子、柳澤厚生

\section{【目的】}

副腎白質ジストロフィー（ALD）では極長鎖飽和脂肪酸の神経鞘への蓄樍によ り神経症状を惹起する。本研究では、長鎖飽和脂肪酸力健康成人の自律神経活 動に影響を与えている可能性について、Hostility(敵意) score、心拍変動を用 いて検討した。

\section{[方法]}

健康な女子学生 84 人 (19.5 \pm 0.9 歳) を対象とし、空腹時血清脂肪酸分画を 測定。心理的負荷として逆算課題を施行、ホルタ一心電図計による連続心電図 記録により心拍変動を解析し、負荷の前・中・後における自律神経活動を算出 した。 Hostility score はMMPI New Japanese Version (1993)から Cook and Medley (1952) の hostility scale を算出した。

\section{【結果】}

Hostility 四分位の高值群において血清中のミリスチン酸（14:0）とパルミチン 酸（16:0）の高値はストレス時の副交感神経活動を高め、抗ストレス効果を呈 した。一方、血清中のアラキジン酸 (20:0)、ベへニン酸 (22:0)、リグノセリ ン酸（24:0）の高値は、逆に副交感神経活動の抑制嚻向を呈した。

\section{[考察]}

ALD では血清極長鎖飽和脂肪酸の高值が神経症状の原因である。炭素数 20〜 24 の長鎖飽和脂肪酸も、その血清濃度が生理的範囲内の変動で自律神経系、 しいては他の神経ネットワークにも影響を与えている可能性がある。

\section{【結論】}

性格的に敵意性の高い若年女性において、炭素数 16 以下の血清飽和脂肪酸は 自律神経系に対し抗ストレス効果を示し、リノール酸や炭素数 20 以上の血清 飽和脂肪酸は、ストレスを助長する可能性が示唆された。 


\section{$\mathbf{P}-9$ \\ ラットの産仔数および母性行動に対する 共役リノール酸給与の影豐}

東農大短栄 1)、アイフォーコム〈株〉2)、桜の聖母短大 3)

○大出要矢子 1)、関口真理子 2)、南 江美子 3)、判上正昭 1)、安原 義 1)

【目的】多価不飽和脂肪酸の多くは機能性脂質であり、細胞膜中および細胞 質での役割が認識され、数々の生理活性をもっていることが明らかとなって きた。我々は、数年前から $\mathrm{n}-6$ 系脂肪酸のラットの母性行動に対寸る影響 を調べている。最近では共役リノール酸のように、乳がんの予防やエネルギ 一代謝を六進する共役脂肪酸の報告も多く見受けられる。そこで、我々はこ れに関連して共役リノール酸(CLA)を給与したときに、ラットの母性行動が どのように変わるかについて検討することを目的とした。

【方法】供試動物 : SD 系ラット 5 週齢を用い、購入時より給与飼料 AIN76 中のコーン油 5\%をサフラワー油 $5 \%$ に置き換えたS 群（対照群）と共役 リノール酸十サフラワー油（3：7）5\%に置き換えた CLA 群（試験群）とに 分けた。S 群は、雄 22 匹、雌 29 匹とし、CLA 群は、雄 20 匹、雌 28 匹と した。なお、飼料および水は、自由摂取とした。慗殖 : 9 週齢になった時、 各群内で繁殖にかけた。測定項目：繁殖率、産仔数、母ラットの臭気探索行 動、生後 3 週にお汀る離乳数を測定した。また、親世代のラットにおいて、 15 週路令䧳の脳の海馬における脂肪酸組成を調べた。

【結果および考察】産仔数：繁殖率はS 群 70.6\%、CLA 群 37.5\%であった。 なお、産仔数は $S$ 群 $(n=12)$ が 111 匹、CLA群（n=6）が 39 匹であっ た。この事から、CLA 給与群は集団遺伝学的意味での適合度が低くなると 推察された。また、摂取脂肪酸が母ラットの生殖細胞に影響したのではない かと推察された。臭気探索行動：誤りの総時間は CLA 群で多くなった。こ の事より、CLA 給与は母ラットの感覚器一特に嗅覚一に影響を与えたので はないかと考えられた。仔の離乳数 : S 群が 81 匹、CLA 群は 14 匹であ った。仔の離乳率は、S 群 70.2\%、CLA 群 33.2\%であった。海馬における 脂肪酸組成： $\mathrm{AA}$ と DHA の比で、S 群の母ラットは AA : DHA=約 $1: 1$ 、 CLA 群の母ラットは約 $1: 2$ であった。これらの現象の機構として、摂取脂 肪酸が主に生体膜に取り込まれ、脳・神経系や内分泌系における、神経伝達 物質やホルモン等の質的・量的変化の原因となり、各種臟器の代謝や動物の 種々の行動にまで影響をおよぼすものと推察している。 


\section{$P-10$ タイ国における血清リン脂質中脂肪酸組成と身体状况、 血清生化学検査值および食品群摄取量との関連}

女子栄養大学栄養学部

○川端輝江、渡邊早苗、金子嘉徳、宮城重二、佐久間充、長谷川恭子

【目的】タイ国バンコク市街地および郊外在住の 50,60 歳代男女 $212 人$ の血清少ン脂質中脂肪酸組成を分析し、身体状況、血清生化学検查值お よび食品群摄取量との関連を検討した。

【方法】調查地区および対象者:タイ国バンコク市街地(A地区Jatujak District)およびバンコク郊外 (B地区、Nonta-buri Province) 住民を対象 とした。対象者は50、60歳代の男女 212 人(A地区およびB地区それぞれ 夫婦単位で53人ずつ)を抽出した。食事調查: 食物摄取頻度調查によっ て日常の食生活を聞き取った。食品の摄取量は頻度と 1 回の摄取量から 計算によって求めた。血液検体: 対象者から空腹時採血を行なった。血液 は空輸後、日本において分析した。血清中リン脂質中脂肪酸濃度は、薄 層クロマトグラフィーによってリン脂質画分を採取、塩酸メタノール法によ ってメチル化、GLCによって分析した。

【結果】B地区は米を主体とした主食の掞取量が高く、それに対して、A 地区では魚介、およびその加工品、野菜、果物、海草の搯取量が高かっ た。また、A地区はB地区に比べてBMIが高く、特に女性では血清レプチ ンが有意に高かった。血清リン脂質脂肪酸組成では、A地区はB地区に比 べてEPA組成およびEPA／AA比が高く、MUFA、18:1n-9、20:3n-6組成 が男女とも有意に低かった。一方、対象者全体で解析した場合、血清リン 脂質中脂肪酸組成のEPAおよびDHA組成、EPA/AA此が高い群では、 魚介類の摄取量が高かった。これは、血清リン脂質脂肪酸組成が魚介類 の掑取量を反映するものであった。さらに、血清リン脂質中 $\Sigma \mathrm{n}-3$ PUFA* $/ \mathrm{AA}$ 平均值は、男性 $0.9 \pm 0.2$ 、女性 $0.9 \pm 0.3$ であった。

【結論】都市化の進んだバンコク市街地と農村地域である郊外では、食 生活に著しい違いが見られ、血清リン脂質脂肪酸組成にも違いが見られ た。また、我々のこれまでの調查では、日本 (沖縄)の同年代人の $\Sigma \mathrm{n}-3$ PUFA／AAは男女とも約1.1前後であったことから、日本(沖縄)に比べタ イの対象者の人では魚介類由来のn-3系PUFAレベルは低く、AAレベル が高いことがわかった。

* $\Sigma \mathrm{n}-3$ PUFA :EPA+DPA+DHA 


\section{Effects of Hilsa Ilsa Fish Oil on Atherogenic Lipid $P-11$ Profile and Glycemic Status of Streptozotocin- treated Type 1 Diabetic Model Rats}

${ }^{1)}$ Department of Biochemistry and Molecular Biology, Jahangirnagar University, Savar, Dhaka, Bangladesh, ${ }^{2}$ Department of Biochemistry and Molecular Biology, University of Dhaka, Dhaka 1000, Bangladesh, ${ }^{3}$ Department of Pharmacology, Research division, BIRDEM, Dhaka, Bangladesh and ${ }^{4}$ Department of Physiology, Shimane Medical University, Izumo, Japan

Shahdat Hossain ${ }^{1)}$, Ishtiaq Mahmud ${ }^{2)}$, Anwar Hossain ${ }^{2)}$, Abdul Hannan ${ }^{3)}$, Liakot Ali $^{3)}$ and Michio Hashimoto ${ }^{4)}$

The effects of oral administration of Hilsa (Hilsa Ilsa) fish oil ( $1 \mathrm{~g}$ oil $/ \mathrm{kg} \mathrm{BW/day)}$ on lipid profile, platelet aggregation, antioxidative status and glycemic control of streptozotocin $(90 \mathrm{mg} / \mathrm{kg} \mathrm{BW})$-treated type 1 diabetic model rats were compared with those of the fish oil-treated or untreated non-diabetic rats.

[Results] After 3-week of fish oil feeding, plasma total cholesterol decreased both in the non-diabetic and diabetic model rats, respectively, by $22 \%$ and $21 \%$, triglyceride by $46 \%$ and $20 \%$, as compared to those of the control rats. Fish oil feeding decreased nonesterified fatty acids (NEFA) by $29 \%$ only in the diabetic model rats but the level of NEFA in non-diabetic rats was not affected. Platelet aggregation decreased by 49 and $37 \%$, and total antioxidant status increased by 18 and $17 \%$, respectively, in the non-diabetic and diabetic model rats after fish oil feeding. Insulin levels increased by $27 \%$ only in the fish-oil fed non-diabetics, while it severely decreased in the diabetic model rats. Glucose levels were not altered at all and fructosamine levels decreased by $29 \%$ only in the fish-oil fed diabetic rats.

[Conclusion] The study suggests that Hilsa Ilsa fish oil may ameliorate the atherogenic lipid profile, platelet hyperaggregation and the antioxidative defense of streptozotocin-treated type 1 diabetes and the amelioration is thought to be independent of its effects on glycemic control. 


\title{
P-12 ムラサキイガイ（Mytilus edulis）の機能性脂質成分
}

\author{
中央水産研究所 \\ 齋藤洋昭
}

【目的】ムラサキイガイ(Mytilus edulis Linnaeus)は、ムール貝と称さ れヨーロッパ原産であるが、昭和初期に船舶を通じ日本全国に広がった。 国内では一部食用とされているが、さほど消費量は多くなく、しばしば 漁網や港湾のブイなどに付着し、その除去に手間取っている。また、有 する化学成分はほとんど明らかになっていない。

そこで本報告では，本種の有効利用のため、脂質成分に着目し、栄養 成分や機能成分を明らかにする。

【方法】神奈川県横浜市沿岸などで採集されたムラサキイガイ軟体部 を，Folchの方法により抽出し，得られた脂質のクラスをシリカゲルカ ラムクロマトグラフィーにより調べた。また，主要クラスの脂肪酸はメ チルエステル化し，組成をキャピラリーカラムガスクロマトグラフィー により調べた。

【結果と考察】ムラサキイガイ軟体部の脂質含量は， $1.5 \pm 0.1 \%$ と低 かった。脂質クラスは，中性脂質ではトリアシルグリセロール（TAG、 $29.7 \pm 6.1 \%)$ が、極性脂質ではホスファチジルエタノールアミン $(\mathrm{PE}$ 、 $18.7 \pm 1.8 \%)$ が主成分であった。他の成分として，ステロール（21.0 $3.5 \%$ ）、遊離脂肪酸（10.2 $\pm 1.0 \%)$ 及び、スフィンゴ脂質（セラミド アミノエチルホスホネート,CAEP、8.4 $\pm 2.0 \%)$ が確認された。相当量 の CAEP を含むことから，ムラサキイガイ軟体部はセラミド供給源の可 能性が見出された。TAGの主要構成脂肪酸は，14:0，16:0，16:1n-7，18 :0，18:1n-9，20:5 n-3（イコサペンタエン酸，EPA），22:6 n-3（ドコサ ヘキサエン酸，DHA）で、PE では 16:1n-7, 18:1n-9，20:2 $\Delta 、 22: 2 \Delta$ 、 EPA，DHA だった。いずれも、高い含量で DHA やEPA などの n-3 高度 不螕和脂肪酸（n-3 PUFA）の割合を有し、また、PEには相当量のノン メチレンインタラプティドジエン酸を含み、二枚貝脂質の特徴を示した。

\section{【結論】}
1)ムラサキイガイの脂質含量は低かった。
2)相当量の CAEPを含んでいた。
3) 中性脂質、極性脂質ともに高含量の EPA と DHA を含んでいた。 


\section{$P ー 13$ 各種酸化条件下におけるトコフェロールの酸化防止能}

成蹊大学工学部 ○原 節子・尾藤泰夫・戸谷洋一郎

【目的】不飽和油脂は光や油脂中に存在する微量の金属，ラジカル，クロロ フィルのような光増感剤などにより自動酸化が促進される。しかし，我が国に おいて油脂類の酸化防止剂として現在最も汎用されているトコフェロール

（Toc）の各種酸化条件下における酸化防止能については不明な点が多い。本 研究においては暗所, UV 照射下, 金属イオン存在下, ラジカル発生剂存在下, 光増感剤存在下における Tocの酸化防止能とホスファチジルエタノールアミン （PE）の酸化防止相乗作用について比較検討した。

【方法】 1) 自動酸化基質 ハイリノールサフラワー油脂肪酸メチルを用い た。2）酸化条件 (1)暗所系, (2)UV（13W）照射系，(3)塩化鉄（II）を基質に 0.005\%添加した系, (4)脂溶性ラジカル発生剤 2,2-アゾビスイソブチロニトリル

（AIBN）を基質に 1\%添加した系，(5)光増感剂であるメチレンブルーを基質に $0.2 \%$ 添加した UV 照射系, (6)メチレンブルーを基質に $0.2 \%$ 添加した暗所系につ いて, $30^{\circ} \mathrm{C}$ 恒温槽中で自動酸化を行った。3) 酸化試験 I 酸化条件(1)〜(6) に いて，それぞれコントロール（暗所・Toc 無添加系)，Toc 無添加系，Toc0.1\% 添加系, Toc0.1\%+PE1\%添加系を設けて試験を行った。4)酸化試験 II (1)(3) (5)6の酸化条件下にそれぞれコントロール（暗所・Toc 無添加系)，PE 無添加 系, PE1\%添加系について試験を行った。5) 分析 ヒドロペルオキシド (LOOH) 量を電位差滴定-過酸化物価（PV）法，共役ジエン量を UV 法，脂肪酸組成を GLC 法, Toc 残存量を HPLC 法によりそれぞれ測定した

【結果と考察】1) 酸化試験 I (2)〜 (6)の酸化条件下では(1)コントロールの $\mathrm{PV}$ が $100 \mathrm{me} / \mathrm{kg}$ に達する時間 1.00 として, 何れの系も酸化が促進されることが 確認された。これらの酸化条件下での Toc および Toc+PE の酸化防止効果を比 較すると, Toc 添加系では(1)；2.29, (2)；1.76, (3)；1.09, (4)；2.03, (5)；2.34, (6) ; 4.55 であった。また, Toc+PE 添加系では(1)；4.39, (2)；1.98, (3)；4.64, (4) ; 2.18, (5)；1.96, (6)；1.86であった。

2）酸化試験 II 酸化試験 I の6にたおてPEの添加効果が認められなかったた め, (1)(3)(5)(6)の酸化条件下に基質に対する PE の影響を検討した。その結果， PE 無添加系の PVが 100me/kg に達する時間を 1.00 とした場合, PE 添加系は(1); 1.01, (3)；1.69, (5)；1.08，(6)；1.33 となり，何れの系においてもPEが基質の 酸化を促進することはなかった。また，(3)ではPE の添加により鉄イオンが捕 捉されるため, 鉄イオンの酸化促進作用を抑制することが確認された。 
成蹊大学工学部 ○原 節子・閑田文人・水上麗子・戸谷洋一郎

【目的】 $\mathrm{n}-3$ 系高度不飽和脂肪酸（PUFA）に富むマグロ眼窩油の 1.3-位のア シル基を n-6 系 PUFA であるリノール酸（LA）や中鎖脂肪酸（MC） と酵素的 に変換することにより，n-6/n-3 比をバランス良くもつ PUFA-TG や n-3PUFA・ MC-TG を効率よく調製する条件を検討した。また，その条件を基本としてハ イリノールサフラワー油へ MC を組込む至適条件についても併せて検討した。

【方法】 1. PUFA-TG の調製 精製マグロ眼裔油を TG 基質，ハイリノール サフラワー油から調製した LA（純度 : 95.2\%）を脂肪酸（FA）基質として， TG/FA を 1/6 のモル比で混合した後，1,3-特異性リパーゼ〔Lipozyme TL-IM (Thermomyces lanuginousus, 75IUN/g)] 又は Lipozyme RM-IM [Rhizomucor miehei,

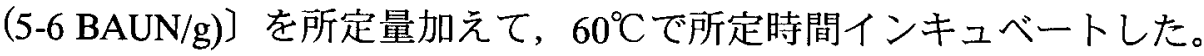

2. n-3PUFA·MC-TGの調製 精製マグロ眼窩油を TG 基質, 市販のカプリル酸 (C8:0)，カプリン酸 (C10:0)，ラウリン酸（C12:0）を FA 基質として, 1/6の モル比で混合した後, Lipozyme RM-IM を所定量加えて $60^{\circ} \mathrm{C} て ゙$ 所定時間インキ ュベートした。

3. LA·MC-TG の調製 ハイリノールサフラワー油を TG 基質, 市販の C8:0, $\mathrm{C} 10: 0, \mathrm{C} 12: 0$ を FA 基質として，1/6のモル比で混合した後，位置特異性のな い Novozym 435 〔Candida Antarctica, 10,000PLU/g] 又は Lipozyme TL-IM TG 基質の $3 / 10$ 倍量加えて $70^{\circ} \mathrm{C}$ で所定時間インキュベートした。

【結果と考察】 1. PUFA-TGの調製 TG 基質 $1 \mathrm{~g}$ に対して Lipozyme TL-IM を 20-80IUN 又は Lipozyme RM-IM 1-12BAUN，反応時間を 4-24h としてインキ ユベートした結果, n-6/n-3 比が 1.3-6.9 までの様々な比率の PUFA-TG を調製で きた。なお，TG 回収率は Lipozyme RM-IM を用いた方が 10-20\%高かった。

2. n-3PUFA·MC-TG の調製 TG 基質 $1 \mathrm{~g}$ に対して Lipozyme RM-IM を 8BAUN 用いて 4-24hインキュベートした結果, TGへの組み込み率は C8:0が 32.7-58.0\%, C10:0が 40.2-53.0\%，C12:0 が 42.8-88.2\%であった。

3. LA·MC-TG の調製 Novozym 435 を用いた場合のアシル基変換率は C8:0 が 37.1\%, C10:0 が 47.1\%，C12:0 が 62.4\%であった。また, Lipozyme TL-IM を 用いた場合は C10:0 が 6.2\%，C12:0が 23.4\%であった。

以上の結果より，TG に対して種々のアシル基を変換する醭素として Lipozyme RM-IM と Novozym 435 の有効性が判明した。 


\section{$P$ - 15 カペリン油のモノ不飽和脂肪酸について}

東京水産大学 ${ }^{1)}$ 、森永乳業株式会社 ${ }^{2}$ 、柳川リハビリテーシ ヨン病院 ${ }^{3)}$

○北村洋平 ${ }^{1)}$ 、押田恭一 ${ }^{2)}$ 、浅野祐三 ${ }^{2)}$ 、田村吉隆 ${ }^{2)}$ 、安徳 恭演 ${ }^{3)}$ 、後藤直宏 ${ }^{1)}$ 、和田 俊 ${ }^{1)}$

【目的】近年、高級モノ不飽和脂肪酸 (C20:1, C 22:1) は、動脈硬化の各 種リスクファクターと有意な相関関係を有する極長鎖飽和脂肪酸 (C26:0な ど)を低下させる効果があり注目されている。カペリン(Mallotus villosus)は、 シシャモとして市場に流通されており、魚体の構成脂肪酸は、モノ不飽和 脂肪酸 (MUFA) に富むことが知られている。そこで本研究では、アイスラン ド産カペリンおよび日本産シシャモ(Sprinchus lanceolatus)に着目し、両 者の脂質成分の相違について脂質クラスおよび脂肪酸組成から比較検討 した。また、現在までカペリン油中の高級モノ不飽和脂肪酸の二重結合位 置は明らかになっていないことから、二重結合位置についても検討した。

【方法】アイスランド産カペリンおよび日本産シシャモより Bligh\&Dyer 法に て総脂質を抽出し、TLC 法にて脂質クラスを、GC 法にて脂肪酸組成を分 析した。また、カペリン油中の C20:1 および C22:1を 4,4-Dimethyloxazoline (DMOX) 誘導体化し、GC-MS により二重 結合の位置を決定した。

【結果】カペリン油およびシシャモ油では、その構成脂肪酸に占めるMUFA の割合は 50\%以上であった。特にカペリン油では、高級モノ不飽和脂肪酸 が約 40\%(C20:1 約 25\%、C22:1 約 15\%)であった。一方、日本産シシャ モ油では高級モノ不飽和脂肪酸は微量であった(C20:1 約 1.5\%、C22:1 約 $0.5 \%)$ 。

カペリン油の高級モノ不飽和脂肪酸の二重結合の位置異性体について は、C20:1 では C 20:1n-11 とC20:1n-9 が約 25\%、およびC $20: 1 n-7$ が約 0.5\%であった。また C $22: 1$ では、C $22: 1 n-11$ が約 $15 \%$ 小よび C $22: 1 n-9$ が約 $2 \%$ あった。

【考察】カペリン油および日本産シシャモ油では MUFA 含量が多く、有力 な MUFA の供給源である。特にカペリン油は高級モノ不飽和脂肪酸に富 み、また、EPAやDHAなどの動脈硬化予防効果を有する多価不飽和脂肪 酸も含むことから動脈硬化予防に有用であることが期待される。

【結論】分類学上別種であるカペリンと日本産シシャモは、脂質栄養学的 知見からもその相違が明らかとなった。特にカペリン油は高級モノ不飽和 脂肪酸に富むことから、今後、動脈硬化予防の機能性食品への応用が期 待される。 


\section{$P-16$ クト血管機能に及ほす食事と連動の影䈉一市民主体型「生活習慣病プロ}

1) 島根医科大学環境生理学、2) 同 - 環境予防医学、3) 島根女子短期大学家政科食物専攻 $\bigcirc$ 橋本道男 ${ }^{1)}$ 、塩飽邦憲 ${ }^{2)}$ 、乃木章子 ${ }^{3)}$ 、藤井由己 ${ }^{1)}$ 、北島桂子 ${ }^{2)}$ 、川北映輔 ${ }^{1)}$ 、 山根洋在 ${ }^{2)}$ 、紫藤 治 ${ }^{1)}$

持続的な血流増加や血中脂質組成变化により血管機能は影響を受けることから、最近では 生活習慣病予防の観点から、血管機能とくに内皮細胞機能と運動・血漿脂質との関連性に ついて興味がもたれている。我々は以前、運動負荷ラットでは、血管拡張物質であるATP の尾動脈内皮細胞からの遊離量が増大する事、さらには、運動によるこれら血管内皮依存 性の機能変化には、血獎・血管壁の脂質代謝が深く関与する可能性を報告した（Am.J. Physiol., 1999)。最近、島根医科大学の生理学実習や、市民主体型「生活習慣病予防プ ログラム」の開発研究に携わる過程で、新規に開発されたトノメトリー法による多機能型 非観血式血圧計測システムを用いてヒトの血管機能評価を試みたところ、興味ある知見が 得られたので報告する。

【万法】: 島根医科大学 3 年生学生（約 200 名)、出雲市・佐田町住民（約 200 名）を対 象に疫学調査を行い、調査表記入方法で食生活、運動量を把握した。また、一部は「運動 により減量と高脂血症を解消する」事を目的とした市民参加の行政介入方式により、循僰 機能・血清脂質組成に及ほす生活活動変化の影響に就いて検討を行った。測定項目：1） インピーダンス式体脂肪率・肥满度指数の測定、2）多機能型非観血式血圧計測システム により計測される、血圧、心拍出量、大・小動脈弾性係数、全身血管抵抗、3）血䊢の総 コレステロール (C)、 LDL-C、HDL-C、中性脂肪、リン脂質（以上は酵素法）、脂肪酸 組成（ガスクロマト法）

【結果】：1）加秢に伴い、大・小動脈弾性係数が低下し、全身血管抵抗は増加した。2） 運動部所属学生は非所属学生に較べて、拡張期血圧・全身血管抵抗が低下し、小動脈弾性 係数と 1 回心拍出量が増加した。3）一日当たりの歩数が介入前後で 2000 歩以上増加し た群（運動改善群）について介入試験前後の測定值を比較すると、小動脈弾性係数が有意 に増加し、体重・拡張期血圧・ウエストヒップ比・総コレステロール・LDL-C・LDL-C $/ \mathrm{HDL}-\mathrm{C}$ 比の低下と、血墏中のエイコサペンタエン酸（EPA）と $\mathrm{NOx}\left(\mathrm{NO}_{2}+\mathrm{NO}_{3}\right)$ 量の増加が認められた。

【考察・結論】: 新規開発された多機能型非観血式血圧計測システムは、圧脈波を解析す ることにより血管機能を評価し、特に小動脈弾性係数の変化は血管内皮細胞機能を反映す ることが示崚されている。本研究結果から、ヒトの場合でも、運動と血墏コレステロール の低下・血漿 EPA 量の増加などの血墏脂質変化により、血管内皮機能が亢進するものと 思われる。 